\title{
ANALISIS KEGAGALAN GROUND ANCHOR PADA TANAH DENGAN KEPADATAN LEPAS LUNAK SAMPAI SEDANG
}

\author{
Lorenzio $^{1}$ dan Chaidir A. Makarim² \\ ${ }^{1}$ Program Studi Sarjana Teknik Sipil, Universitas Tarumanagara, Jl. Letjen S. Parman No.1 Jakarta \\ Email: lorenziolorenzio322@gmail.com \\ ${ }^{2}$ Program Studi Sarjana Teknik Sipil, Universitas Tarumanagara, Jl. Letjen S. Parman No.1 Jakarta \\ Email: chaidir259@gmail.com
}

\begin{abstract}
ABSTRAK
Pada proses pembangunan suatu konstruksi kerap dijumpai pekerjaan penggalian basement, yang dilakukan dari permukaan tanah sampai pada kedalaman tertentu sesuai dengan kebutuhan pembangunan konstruksi tersebut Konstruksi galian basement lazim menggunakan dinding penahan tanah yang disokong oleh komponen struktur penyokong.. Struktur penyokong tersebut dapat berupa ground anchor, soil nailing, dan lain-lain yang bekerja saling memperkuat dengan dinding penahan tanah. Namun pada beberapa kasus, sering dijumpai adanya kegagalan konstruksi galian basement yang melibatkan komponen struktur ini. Kasus kegagalan konstruksi galian basement yang belum lama terjadi di Indonesia merupakan suatu contoh kasus kegagalan nyata pada komponen struktur tersebut, hal tersebut diduga terjadi karena kesalahan konsultan struktur dalam perancangan serta diperburuk dengan kondisi di lapangan yang bermasalah sehingga struktur penyokong yang semula bertujuan untuk memperkuat dinding penahan tanah tidak dapat berfungsi secara optimal. Penelitian ini akan mengupas penyebab gagalnya ground anchor dengan melakukan simulasi galian basement secara komprehensif sesuai dengan data aktual lapangan.
\end{abstract}

Kata kunci: kegagalan, galian, basement, ground anchor

\section{PENDAHULUAN}

Pada proses pembangunan suatu konstruksi kita sering menjumpai pekerjaan penggalian yang dilakukan dari permukaan tanah sampai pada kedalaman tertentu sesuai dengan kebutuhan pembangunan konstruksi tersebut.Proses penggalian ini dapat dilaksanakan secara langsung maupun bertahap tergantung kedalaman penggalian, jenis tanah, sudut penggalian, dan luas lahan pembangunan sebuah konstruksi.

Dalam konstruksi galian dengan penahan diperlukan konstruksi dinding penahan tanah agar tanah disamping galian tidak tergelincir. Struktur penyokong tersebut bisa berupa ground anchor atau jangkar tanah, dan lain lain.

Namun pada beberapa kasus, perancangan struktur penyokong yang dilakukan oleh seorang ahli teknik sipil mengalami kegagalan, hal ini disebabkan oleh beberapa faktor seperti kesalahan dalam perancangan, kondisi tanah di lapangan yang bermasalah, sehingga struktur penyokong yang semula bertujuan untuk memperkuat dinding penahan tanah tidak dapat berfungsi secara optimal sehingga terjadi kegagalan pada struktur penyokong tersebut.

Kegagalan pada struktur penyokong dapat mengakibatkan longsor, hal ini dapat mengganggu pelaksanaan pekerjaan konstruksi seperti membahayakan para pekerja, mengganggu akses mobilitas pengiriman barang untuk pekerjaan konstruksi, menggangu fasilitas umum berupa jalan raya, pasokan listrik, dan juga yang terburuk dapat mengganggu konstruksi yang sebelumnya sudah jadi disekitar lokasi kegagalan galian tanah.

Pada bahasan kali ini, objek yang akan dijadikan bahan penelitian adalah gagalnya struktur penyokong dinding penahan tanah ground anchor pada salah satu proyek galian basement di Indonesia, pada proyek ini, kegagalan disebabkan perancangan struktur penyokong serta dinding penahan tanah yang kurang tepat untuk kedalaman yang diinginkan oleh perencana sipil serta kondisi tanah yang kurang baik sehingga mengakibatkan longsor pada jalan sekitar proyek tersebut.

\section{METODOLOGI PENELITIAN}

\section{Studi Literatur}

Penelitian dimulai dengan mengumpulkan teori untuk analisis penyebab kegagalan ground anchor pada konstruksi dermaga pada salah satu kawasan pulau di Indonesia berupa buku, jurnal, dan peraturan seperti Geotechnical 
Circular no.4: Ground Anchor and Anchorage System dan SNI 8460:2017 tentang Persyaratan Perancangan Geoteknik.

\section{Pengumpulan dan Pengolahan Data}

Data yang dikumpulkan berupa data boring log, proving test ground anchor. Jenis ground anchor yang digunakan adalah temporary ground anchor 3 buah dengan panjang angkur paling atas 28 meter dan 29 meter untuk 2 angkur dibawahnya. Data-data boring log akan dikorelasikan sehingga mendapatkan parameter yang dibutuhkan untuk menganalisa penyebab kegagalan ground anchor, dan data proving test ground anchor dan shop drawing digunakan untuk menganalisa ground anchor yang mengalami kegagalan.

\section{PEMODELAN DENGAN BANTUAN PROGRAM}

\section{Data yang Digunakan}

Data yang telah dikumpulkan berupa data boring log serta data proving test dapat digunakan untuk melakukan pemodelan pada program. Data yang telah dikumpulkan berasal dari salah satu wilayah di Indonesia yang tidak diperbolehkan untuk dipublikasi. Sehingga, berikut adalah kesimpulan parameter yang diperlukan untuk digunakan pada program.

Tabel 1 Hasil Korelasi Berat Jenis Tanah (Data Proyek Wilayah Indonesia)

\begin{tabular}{cc}
\hline Depth & Gamma Sat $\left(\mathrm{gr} / \mathrm{cm}^{3}\right)$ \\
\hline $0-15$ & 1,65 \\
\hline $15-50$ & 2,15 \\
\hline
\end{tabular}

Tabel 2 Hasil Korelasi Modulus Elasticity dan Poisson’s Ratio (Data Proyek Wilayah Indonesia)

\begin{tabular}{ccc}
\hline Depth & Modulus Elasticity & Poisson's Ratio \\
\hline $0-10$ & 20000 & 0,4 \\
\hline $10-12$ & 5000 & 0,35 \\
\hline $12-15$ & 20000 & 0,49 \\
\hline $15-20$ & 15000 & 0,25 \\
\hline $20-50$ & 30000 & 0,3 \\
\hline
\end{tabular}

\section{Pemodelan Galian}

Pertama kali dalam memodelkan kedalam program terlebih dahulu menggambarkan garis setiap lapisan tanah sesuai dengan jenis tanah, serta garis dari setiap komponen struktur pada tanah yaitu dinding penahan tanah serta ground anchor. Setelah menggambarkan garis yang diperlukan, kemudian dilanjutkan dengan menggambarkan region sehingga garis yang telah digambarkan membentuk region. Gambar garis serta region dari lapisan tanah serta struktur pendukungnya dapat dilihat pada gambar 1 berikut

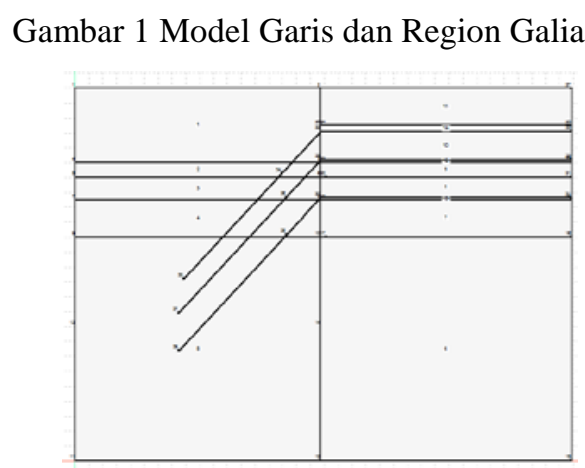

Setelah menggambarkan garis serta region, selanjutnya adalah menentukan material dari setiap lapisan tanah, sesuai dengan korelasi data tanah yang telah dilakukan sebelumnya, dapat dilihat pada gambar 2 sampai gambar 6 berikut 
Gambar 2 Material Tanah Layer 1

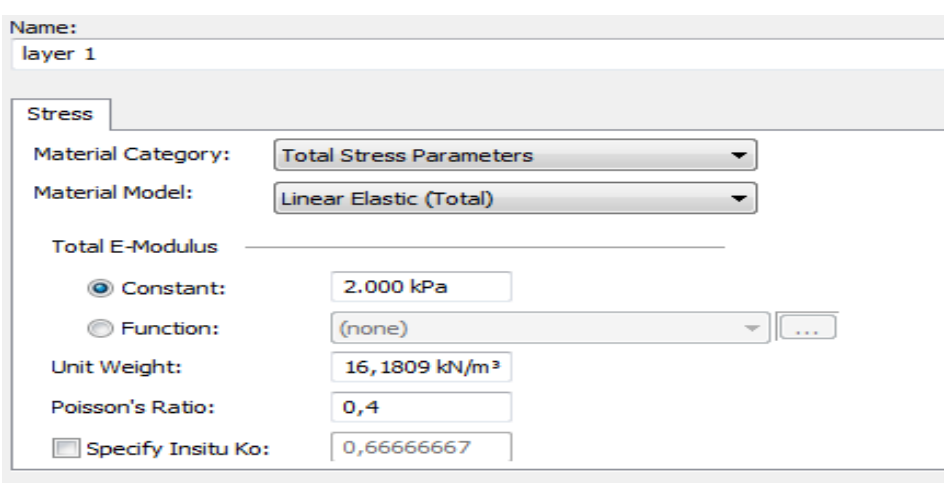

Gambar 3 Material Tanah Layer 2

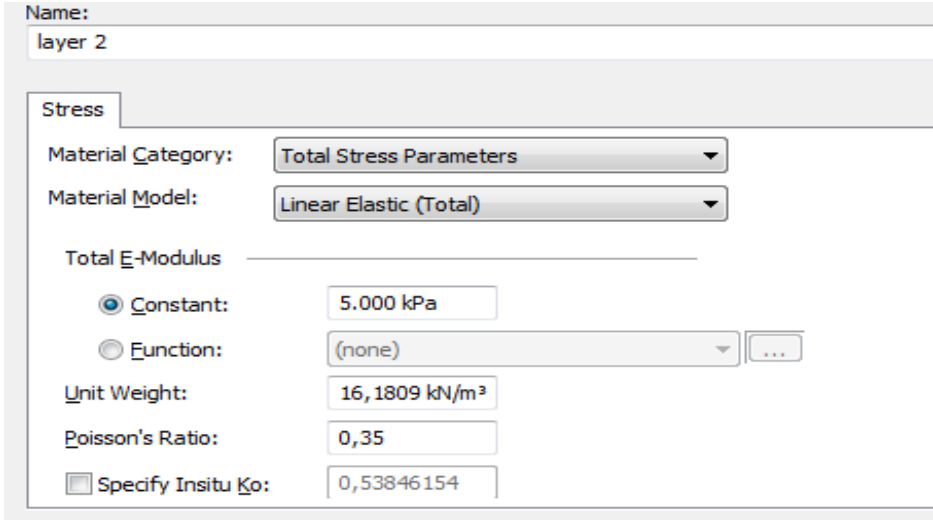

Gambar 4 Material Tanah Layer 3

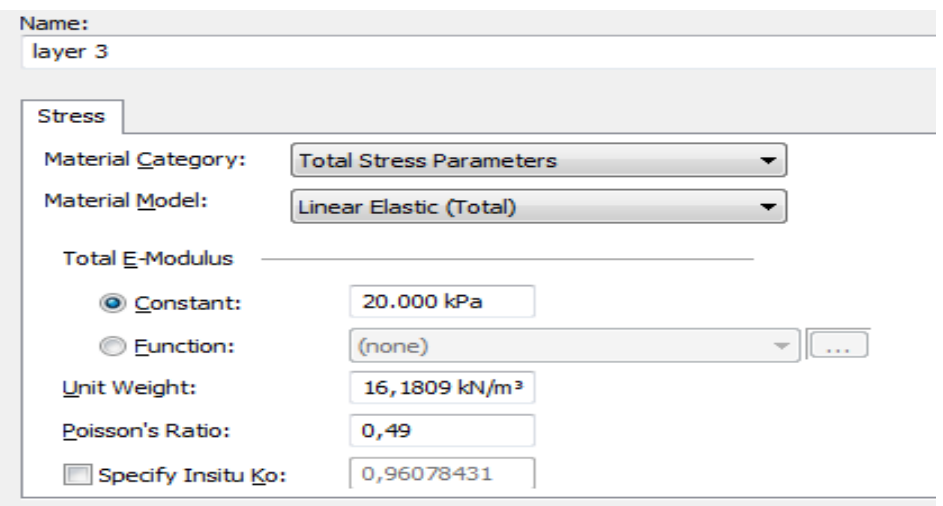

Gambar 5 Material Tanah Layer 4

\begin{tabular}{|c|c|c|c|}
\hline \multicolumn{4}{|l|}{ layer 4} \\
\hline \multicolumn{4}{|l|}{ Stress } \\
\hline Material Category: & Total Stress Parameters & - & \\
\hline Material Model: & Linear Elastic (Total) & - & \\
\hline \multicolumn{4}{|l|}{ Total E--Modulus } \\
\hline () Constant: & $15.000 \mathrm{kPa}$ & & \\
\hline Function: & (none) & - & $\ldots$ \\
\hline Unit Weight: & $21,0843 \mathrm{kN} / \mathrm{m}^{3}$ & & \\
\hline Poisson's Ratio: & 0,25 & & \\
\hline$\square$ Specify Insitu Ko: & 0,33333333 & & \\
\hline
\end{tabular}


Gambar 6 Material Tanah Layer 5

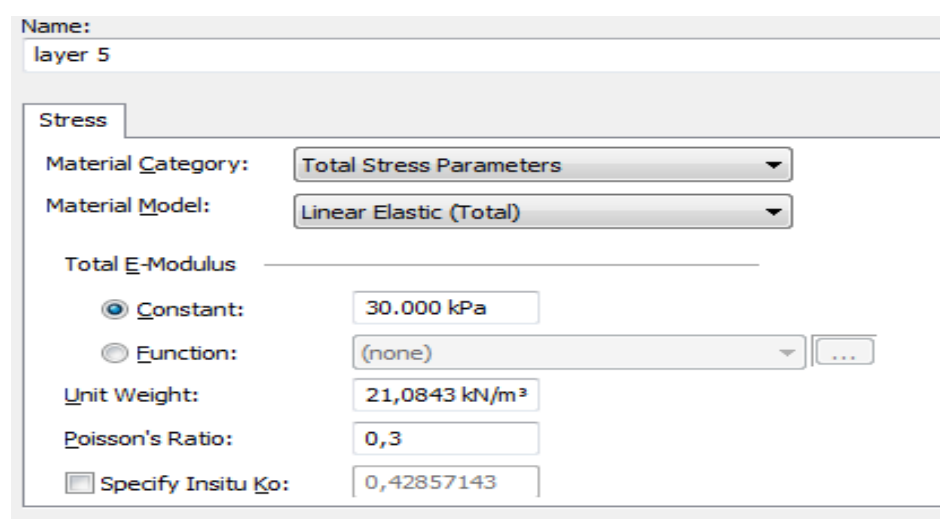

Setelah menentukan material dari tanah, selanjutnya menentukan dinding penahan tanah serta angkur bagian bond length yang diasumsikan sebagai structural beams. Dapat dilihat pada gambar 7 sampai 9 berikut.

Gambar 7 Properties dari Dinding Penahan Tanah

\begin{tabular}{|c|c|c|}
\hline \multicolumn{3}{|l|}{ Name: } \\
\hline \multicolumn{3}{|l|}{ secant piles } \\
\hline E-Modulus: & $23.500 .000 \mathrm{kPa}$ & \multirow[b]{3}{*}{ ( $)$ Allow Compression } \\
\hline Cross-sectional Area: & $0,5027 \mathrm{~m}^{2}$ & \\
\hline Moment of Inertia: & $0,0012566371 \mathrm{~m}^{d}$ & \\
\hline
\end{tabular}

Gambar 8 Properties Bond Length dari Ground Anchor Pertama

\begin{tabular}{ll} 
Name: & \\
\hline anchor 1 & \\
E-Modulus: & $1,9121006 \mathrm{e}+08 \mathrm{kPa}$ \\
\hline Cross-sectional Area: & $0,0314 \mathrm{~m}^{2}$ \\
Moment of Inertia: & $7,8539816 \mathrm{e}-05 \mathrm{~m}^{4} \quad \square$ Allow Tension Compression \\
\hline
\end{tabular}

Gambar 9 Properties Bond Length dari Ground Anchor Kedua dan Ketiga

\begin{tabular}{|c|c|c|}
\hline \multicolumn{3}{|l|}{ Name: } \\
\hline \multicolumn{3}{|l|}{ anchor $2 \& 3$} \\
\hline E-Modulus: & $1,9121006 \mathrm{e}+08 \mathrm{kPa}$ & \\
\hline Cross-sectional Area: & $0,0314 \mathrm{~m}^{2}$ & $\nabla$ Allow Iension \\
\hline Moment of Inertia: & $7,8539816 \mathrm{e}-05 \mathrm{~m}^{d}$ & $\nabla$ Allow Compression \\
\hline
\end{tabular}

Selanjutnya menentukan properties dari free length dari setiap angkur yang diasumsikan sebagai structural bars, dapat dilihat pada gambar 10 dan 11 berikut.

Gambar 10 Properties Free Length dari Ground Anchor Pertama

\begin{tabular}{|c|c|}
\hline \multicolumn{2}{|l|}{ Name: } \\
\hline angtaur 1 & \\
\hline E-Modulus: & 1.9121006e+0B $\mathrm{kPE}$ \\
\hline Cross-sectional Area: & $0,0314 \mathrm{~m}^{2}$ \\
\hline Pre-Axial Force: & $-92 \mathrm{kr}$ \\
\hline
\end{tabular}


Gambar 11 Properties Free Length dari Ground Anchor Kedua dan Ketiga

\begin{tabular}{|c|c|}
\hline \multicolumn{2}{|l|}{ Name: } \\
\hline anglour 283 & \\
\hline E-Modulus: & 1.9121006E+DE $\mathrm{kPa}$ \\
\hline Cross-sectional Area: & $0.0314 \mathrm{~m}^{2}$ \\
\hline Fre-Axial Force: & $-92 \mathrm{kN}$ \\
\hline
\end{tabular}

Setelah selesai menentukan material dari setiap lapisan tanah dan juga struktur pendukungnya, selanjutnya menggambarkan material dari tanah tersebut kedalam region seperti pada gambar 1 di atas. Dapat dilihat pada gambar 12 berikut

Gambar 12 Layer Tanah yang Telah Digambarkan Kedalam Region

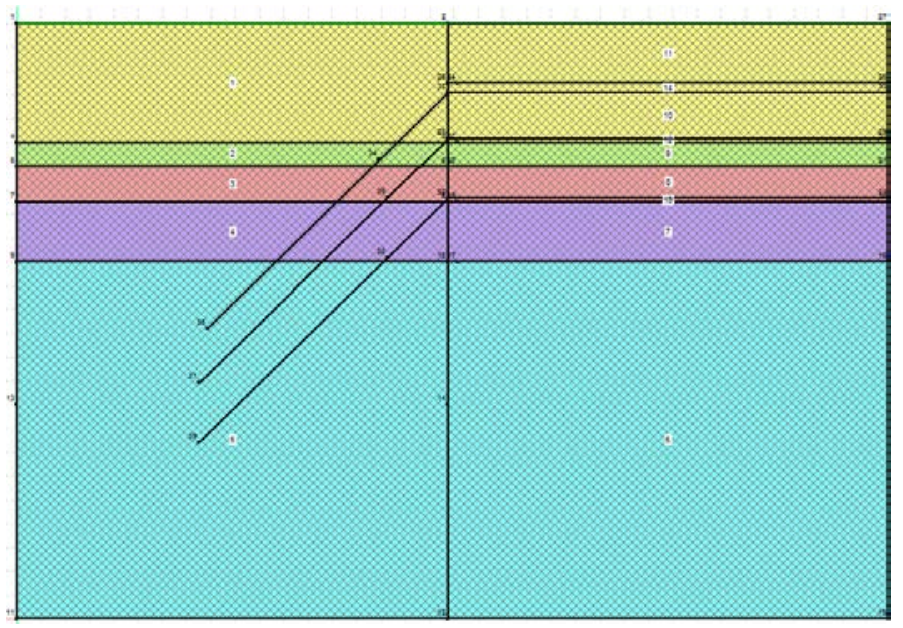

\section{Pemodelan Galian}

Setelah menggambarkan material tanah kedalam region, dilanjutkan dengan proses penggalian tahap pertama serta pemasangan dinding penahan tanah. Tahapan pertama adalah dengan menggambarkan boundary condition pada bagian samping kiri, kanan, dan bawah, serta menghilangkan materia tanah sesuai dengan kedalaman galian. Dapat dilihat pada gambar 13

\section{Gambar 13 Boundary Condition Serta Galian Tahap Pertama}

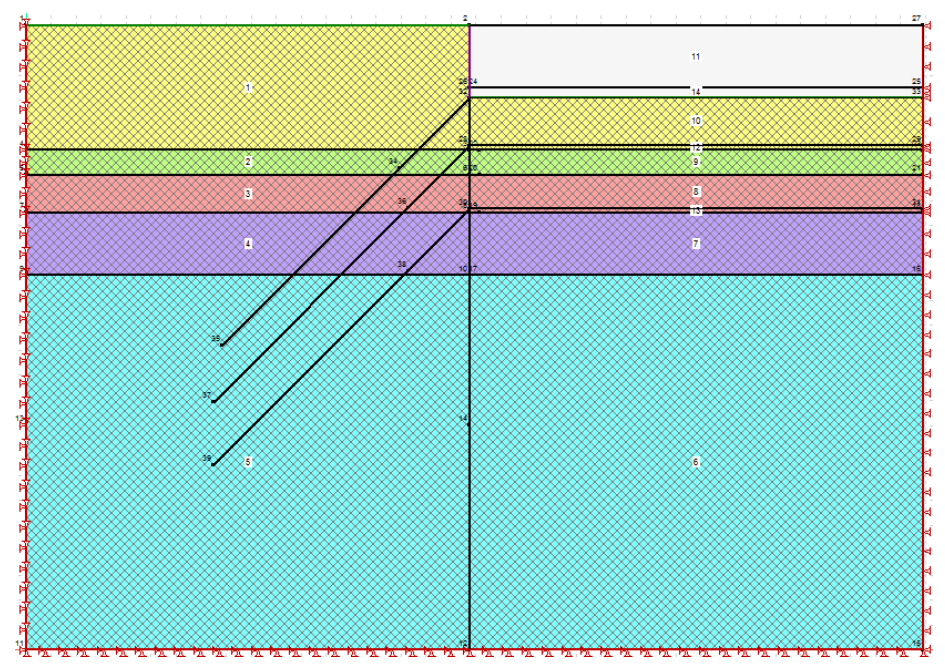

setelah menggambarkan boundary condition pada bagian samping kiri, kanan, dan bawah, dilanjutkan dengan menggambarkan structural beams pada garis yang mewakili dinding penahan tanah sesuai dengan gambar 7 diatas. Structural beams yang telah digambar dapat dilihat pada gambar 14 berikut. 
Gambar 14 Dinding Penahan Tanah Pada Model Galian

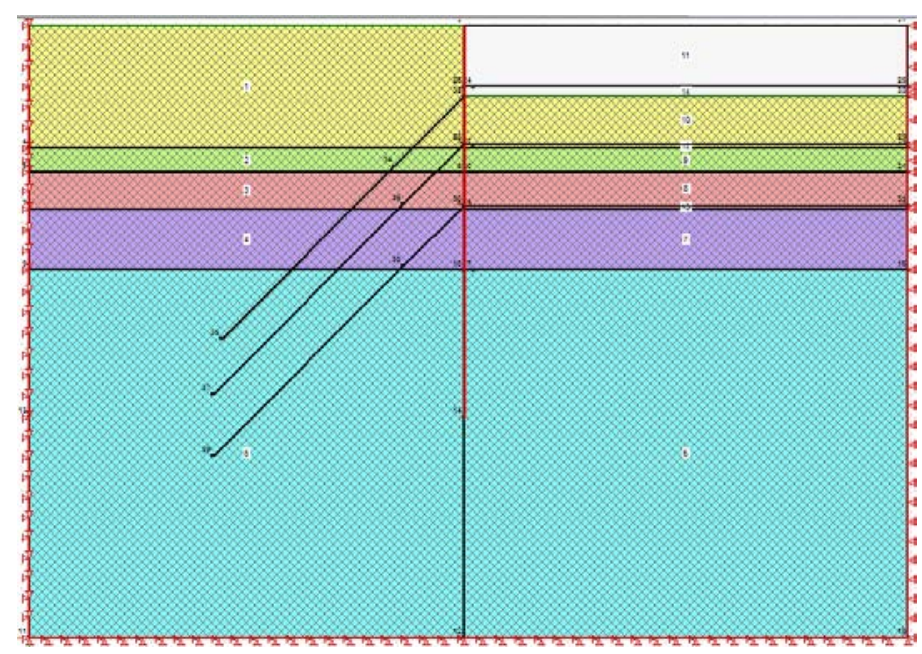

Setelah menggambarkan structural beams dilanjutkan dengan menggambarkan kembali boundary condition pada bagian atas galian untuk mewakili terjadinya pengangkatan tanah yang digali, dapat lihat pada gambar 15 serta 16 berikut

\section{Gambar 15 Boundary Condition Untuk Galian Tahap Pertama}

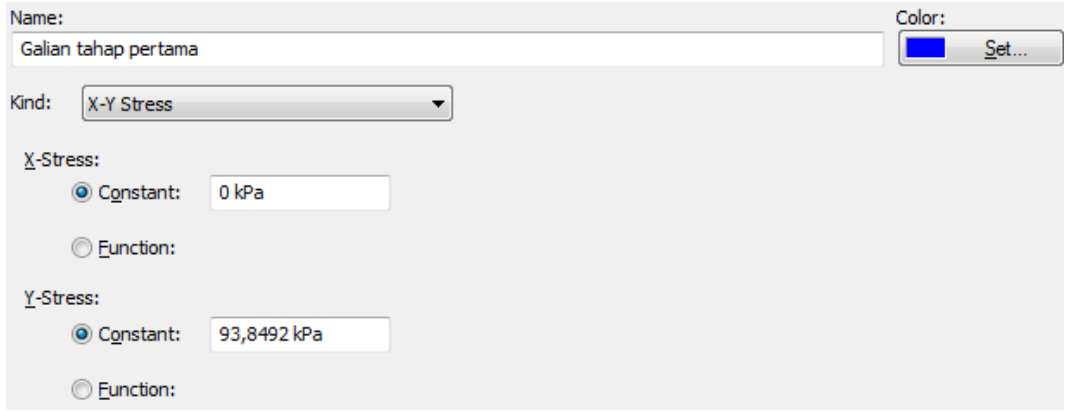

Gambar 16 Boundary Condition Tahap Pertama Setelah Digambarkan Pada Galian

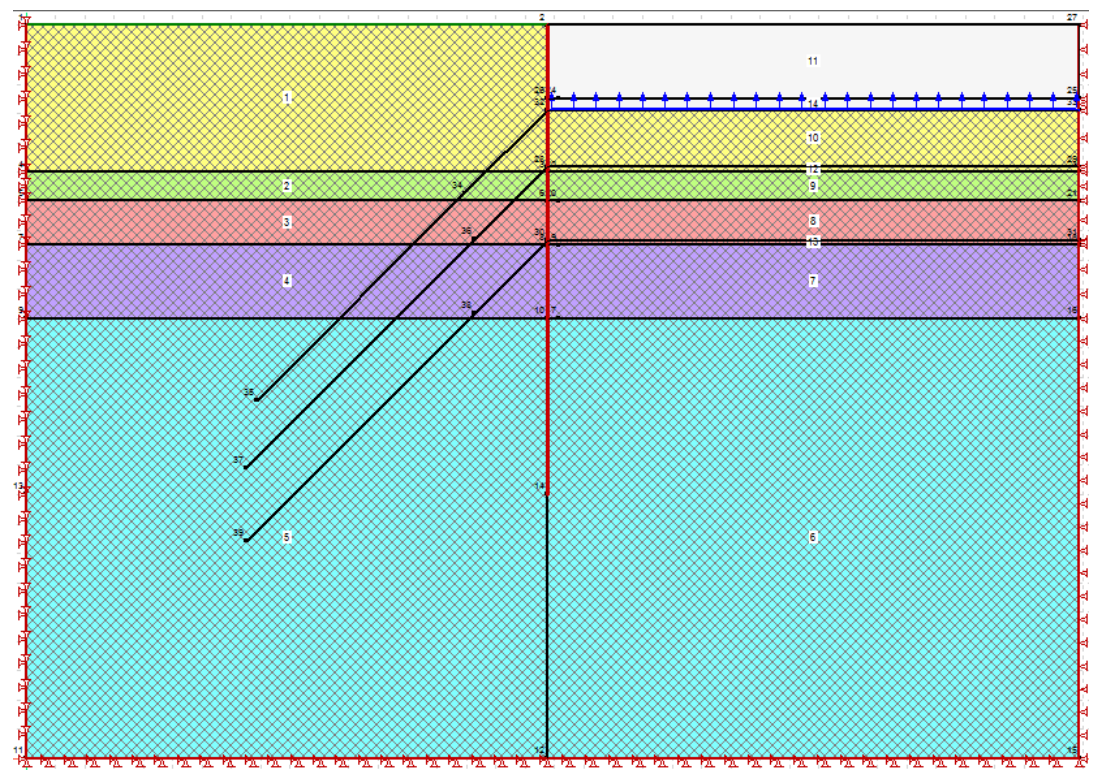

Setelah memodelkan galian tahap pertama (lantai LG) dilanjutkan dengan pemasangan ground anchor untuk lantai LG. Pertama kali dengan menggambarkan free length dengan structural bars yang besarannya sesuai dengan gambar 10 di atas, kemudian selanjutnya menggambarkan bond length yang besarannya sesuai dengan gambar 8 di atas, pemasangan ground anhcor dapat dilihat pada gambar 17 berikut. 
Gambar 17 Pemasangan Ground Anchor Pada Galian Tahap Pertama

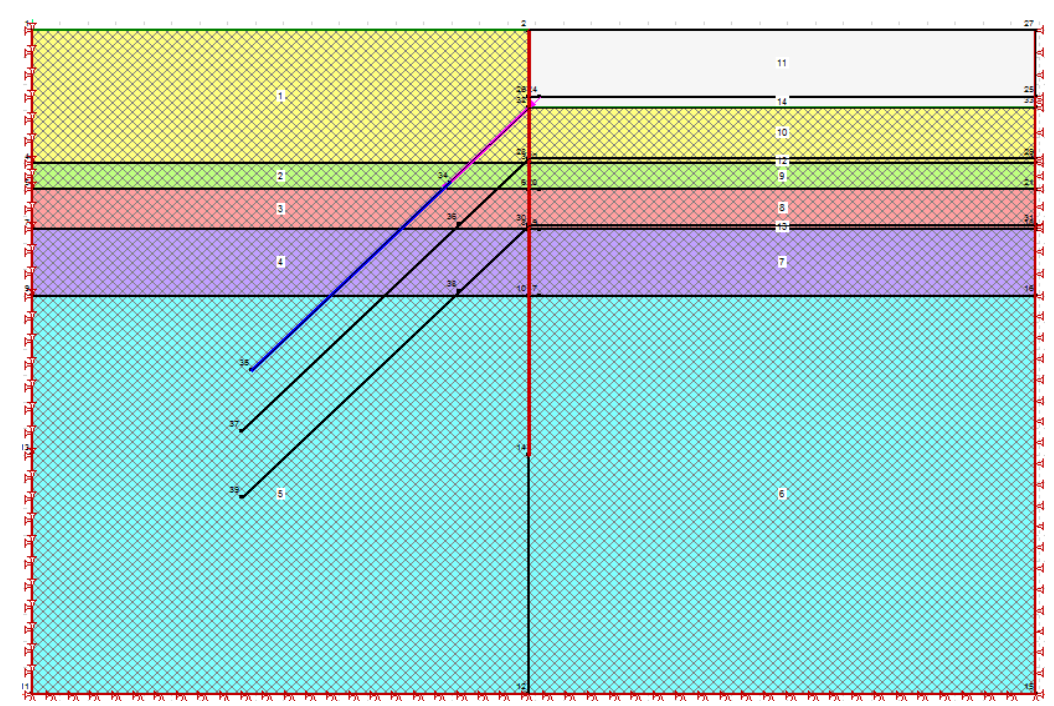

Untuk galian tahap kedua, proses yang dilakukan untuk memodelkan pada program serupa dengan galian pada tahap pertama, dilakukan dengan menghilangkan terlebih dahulu material dari tanah sesuai dengan kedalaman galian tahap kedua, setelah itu dilanjutkan dengan menambahkan boundary condition pada bagian atas galian yang mewakili terjadinya penggalian tanah tahap kedua. Dapat dilihat pada gambar 18 sampai 20 berikut.

Gambar 18 Boundary Condition Untuk Galian Tahap Kedua

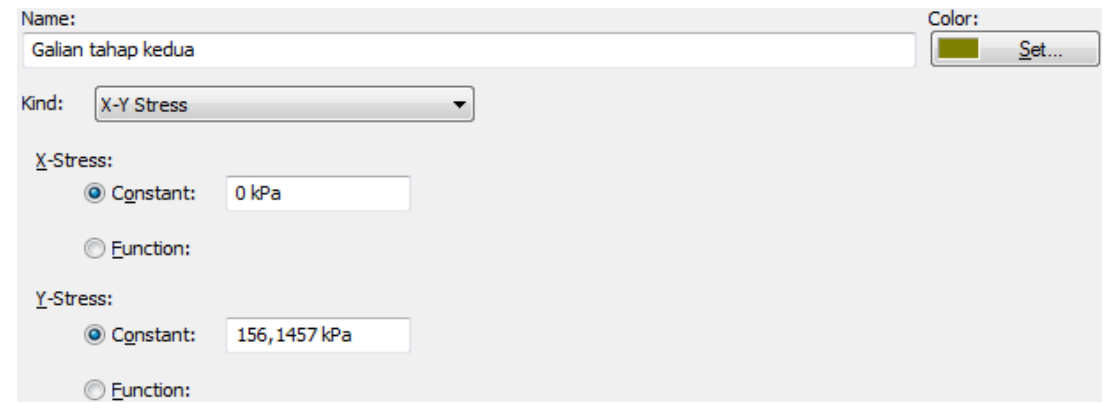

Gambar 19 Boundary Condition Tahap Pertama Setelah Digambarkan Pada Galian

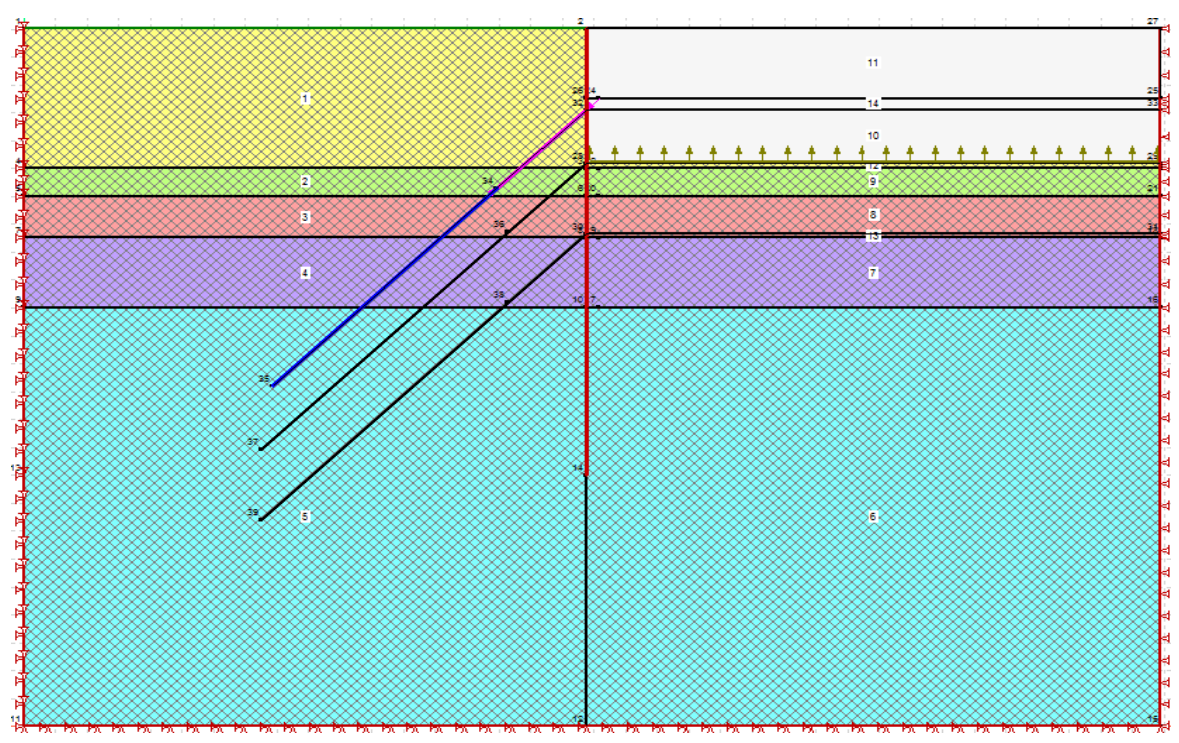

Setelah menggambarkan boundary condition yang mewakili terjadinya penggalian tahap kedua, dilanjutkan dengan pemasangan ground anchor untuk galian tahap kedua. Dengan menggambarkan free length dengan structural bars yang besarannya sesuai dengan gambar 11 di atas, kemudian selanjutnya menggambarkan bond length yang 
besarannya sesuai dengan gambar 9 di atas. Pemasangan angkur untuk galian tahap kedua dapat dilihat pada gambar 20 berikut.

Gambar 20 Pemasangan Ground Anchor Pada Galian Tahap Kedua

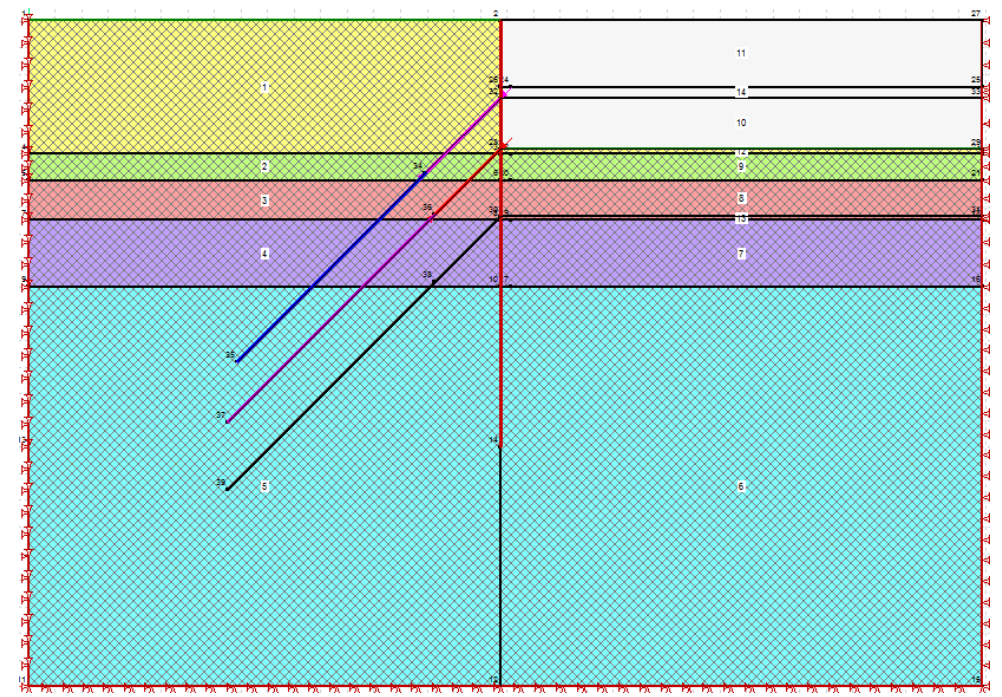

Setelah Memodelkan Pada Galian Tahap Kedua, langkah yang sama dilakukan untuk memodelkan galian tahap ketiga, besaran boundary condition untuk galian tahap ketiga dapat dilihat pada gambar 21 berikut

Gambar 21 Boundary Condition Untuk Galian Tahap Ketiga

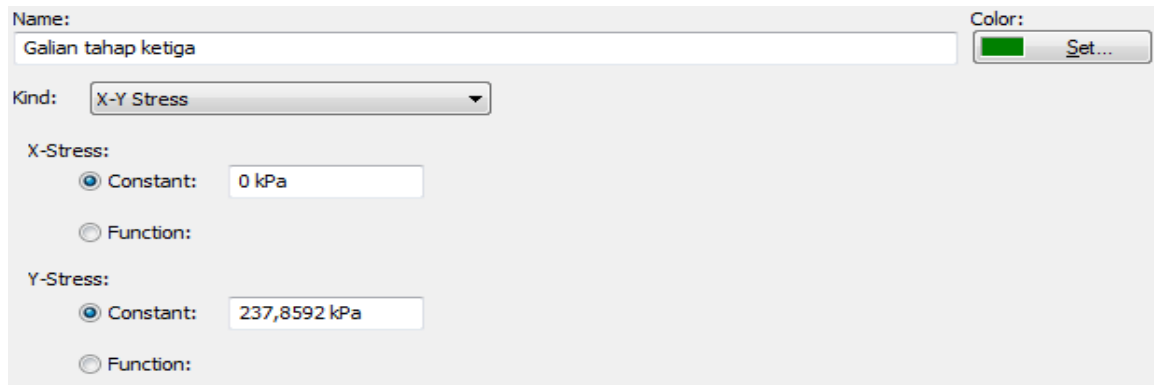

Setelah menentukan besaran boundary condition pada galian tahap ketiga, dilanjutkan dengan menggambarkan kembali boundary condition untuk mewakili pengangkatan tanah, yang kemudian dilanjutkan dengan pemasangan angkur tahap ketiga. Dapat dilihat pada gambar 22 berikut

Gambar 22 Pemasangan Ground Anchor Pada Galian Tahap Ketiga

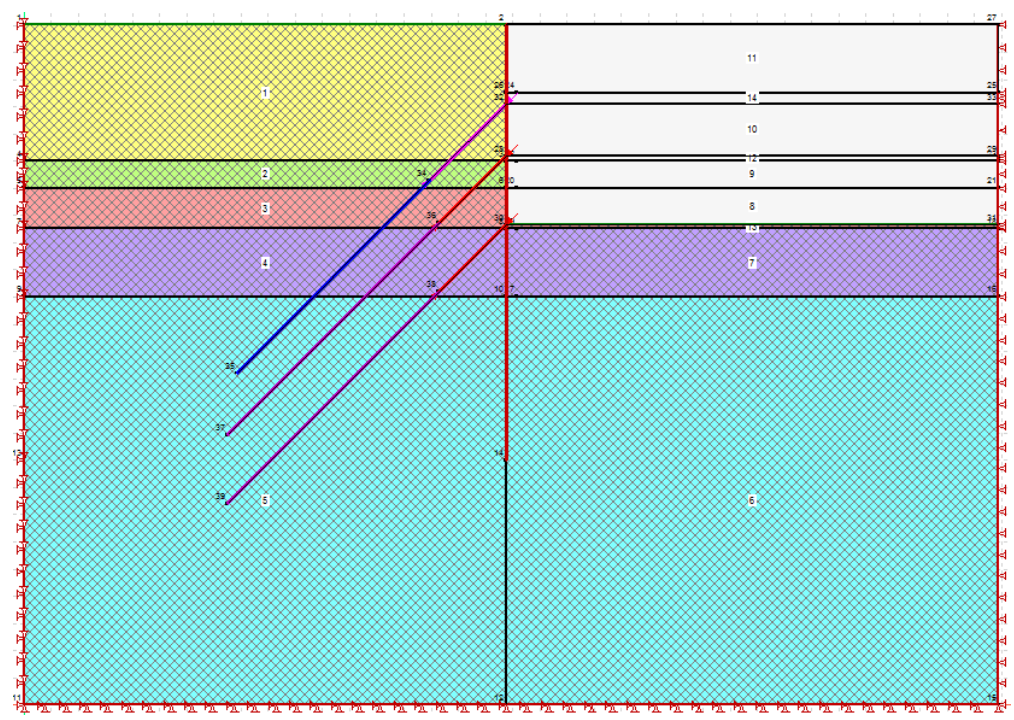




\section{Hasil Analisis Program dan Pembahasan}

Setelah selesai memodelkan seluruh galian dari tahap pertama hingga tahap ketiga, selanjutnya hasil dari pemodelan ini dapat mulai dianalisis, sehingga mendapatkan hasil displacement, serta gaya lainnya yang bekerja disetiap komponen struktur pendukung. Hasil dari setiap gaya yang bekerja pada komponen struktur pendukung tanah dapat dilihat pada tabel 3 sampai 5 berikut

Tabel 3 Displacement, Axial, Moment Yang Terjadi Pada Angkur

\begin{tabular}{ccccccc} 
& \multicolumn{2}{c}{ Diplacement (m) } & \multicolumn{2}{c}{ Axial (kN) } & \multicolumn{2}{c}{ Moment (kNm) } \\
\cline { 2 - 7 } & Depth (m) & Max Value & Depth (m) & Max Value & Depth (m) & $\begin{array}{c}\text { Max } \\
\text { Value }\end{array}$ \\
\hline angkur ke - 1 & 20 & 0,494 & 0 & 3004,048 & 28 & 195,653 \\
\hline angkur ke - 2 & 21,8 & 0,489 & 22,2 & $-2503,181$ & 29 & 553,197 \\
\hline angkur ke - 3 & 23,8 & 0,341 & 0 & 1798,345 & 29 & 148,643 \\
\hline
\end{tabular}

Tabel 4 Shear, Max Strain, Min Strain Yang Terjadi Pada Angkur

\begin{tabular}{ccccccc} 
& \multicolumn{2}{c}{ Shear $(\mathrm{kN})$} & \multicolumn{2}{c}{ Max Strain } & \multicolumn{2}{c}{ Min strain } \\
\cline { 2 - 7 } & Depth $(\mathrm{m})$ & Max Value & Depth $(\mathrm{m})$ & Max Value & Depth $(\mathrm{m})$ & $\begin{array}{c}\text { Max } \\
\text { Value }\end{array}$ \\
\hline angkur ke - 1 & 20 & 63,874 & 20 & 0,064 & 20 & 0,048 \\
\hline angkur ke - 2 & 22,7 & 368,093 & 29 & 0,018 & 29 & 0,00846 \\
\hline angkur ke - 3 & 29 & 247,954 & 23,8 & 0,0233 & 29 & 0,00727 \\
\hline
\end{tabular}

Tabel 5 Total Stress Yang Terjadi Pada Angkur

\begin{tabular}{ccc}
\cline { 2 - 3 } & \multicolumn{2}{c}{ Total Stress (MPa) } \\
\cline { 2 - 3 } & Depth (m) & Max Value \\
\hline angkur ke - 1 & 18 & 58,9238 \\
\hline angkur ke - 2 & 23,8 & 221,7631 \\
\hline angkur ke - 3 & 23,8 & 178,5632 \\
\hline
\end{tabular}

Gaya aksial yang terjadi lebih pada ketiga angkur lebih besar dibandingkan dengan max stressing force yang telah direncanakan yaitu sebesar $1472 \mathrm{kN}$. Sedangkan besaran total stress yang terjadi sudah melebihi dari yield stress dari mutu baja angkur yang digunakan yaitu sebesar $37 \mathrm{MPa}$. sehinga dapat disimpulkan bahwa kegagalan angkur dapat terjadi secara katastropik.

\section{KESIMPULAN}

1. Gaya aksial yang terjadi lebih pada ketiga angkur lebih besar dibandingkan dengan max stressing force yang telah direncanakan yaitu sebesar $1472 \mathrm{kN}$. Sedangkan besaran total stress yang terjadi sudah melebihi dari yield stress dari mutu baja angkur yang digunakan yaitu sebesar $37 \mathrm{MPa}$. sehinga dapat disimpulkan bahwa kegagalan angkur dapat terjadi secara katastropik

2. Kondisi dari galian sudah cukup lama ditinggal sehingga tanah disekitar lokasi mengalami creep akibat adanya beban dinamik dari jalan raya disekitar lokasi proyek

3. Air hasil dewatering dibuang langsung kedalam saluran drainase kota, sehingga menyebabkan terjadinya rembesan air dari arah luar dinding penahan tanah selama kurang lebih 7.5 bulan. Rembesan tersebut menyebabkan turunnya elevasi muka air tanah sekitar \pm 10 meter, dan tegangan vertikal efektif dari tanah meningkat.

4. Pada bagian dinding penahan tanah sebelah timur yang mengalami kegagalan terjadi erosi piping pada butiran pasir lepas yang halus, hal ini disebabkan karena adanya rembesan air ekstra dari air dewatering yang dibuang langsung melalui saluran drainase yang relatif tidak kedap air pada bagian sambungannya dan tanah karena tanah disekitarnya berupa tanah berpasir, air dewatering yang dibuang masuk kembali kedalam tanah, sehingga 
menyebabkan tanah menjadi jenuh air dan terjadi rembesan air tambahan kedalam tanah galian, yang meningkatkan beban pada tanah.

5. Angkur hanya dirancang terhadap gaya tarik normal saja, beban ekstra tersebut menyebabkan gaya tarik berlebih pada angkur yang melampaui kekuatan leleh dari kabel baja, sehingga angkur menjadi gagal dan putus

6. Kegagalan dari angkur tanah menyebabkan dinding penahan tanah tidak lagi mampu menahan gaya lateral tanah yang berada dibelakangnya sehingga kelongsoran tidak dapat dihindari.

7. Runtuhnya dinding penahan tanah mengakibatkan tanah dibelakangnya mengalami kelongsoran kearah galian yang diikuti dengan kelongsoran dari jalan raya disekitar lokasi kejadian.

8. Adanya penemuan kepala dari angkur yang terlepas dilapangan beberapa hari sebelum terjadi kelongsoran

\section{DAFTAR PUSTAKA}

Das, Braja M. (2002). Mekanika Tanah (Prinsip-Prinsip Rekayasa Geoteknis) Jilid 2. Jakarta: Penerbit Erlangga.

Hunt. Roy E. (2005). Geotechnical Engineering Investigation Handbook Second Edition. New York: Taylor \& Francis Group

Ubani. Obinna. (2017). Solved Example on Elastic Settlement of Foundations. Diakses pada 21 Maret 2019 Melalui https://www.structville.com/2017/06/solved-example-on-elastic-settlement-of.html 